\title{
ПОРІВНЯЛЬНИЙ АНАЛІЗ АСОРТИМЕНТУ М'ЯКИХ ЛІКАРСЬКИХ ЗАСОБІВ НА ФАРМАЦЕВТИЧНОМУ РИНКУ УКРАЇНИ
}

\author{
Т. А. Грошовий, І. В. Блажко, А. Ю. Ширко, Б. В. Павлюк, М. Б. Чубка \\ Тернопільський національний медичний університет імені І. Я. Горбачевського МОз \\ України \\ bohdana.vons@gmail.com
}

ІНФОРМАЦІЯ

Надійшла до редакції / Received: 22.10.2020

Після доопрацювання / Revised: 29.10.2020

Прийнято до друку / Accepted: 03.11 .2020

\section{Ключові слова:}

м'які лікарські форми; фрармацевтичний ринок; асортимент.

\begin{abstract}
АНОТАЦІЯ
Мета роботи. Дослідити асортимент ЛЗ у вигляді МЛФ, що зареєстровані на фрармацевтичному ринку України станом на 2019 р., та провести порівняльний аналіз зміни асортименту досліджуваних ЛФ впродовж 5 років (станом на 2014 р.).

Матеріали і методи. Використовували офріційні джерела інформації про зареєстровані в Україні ЛЗ у МЛФ та попередні результати маркетингових досліджень. При проведенні дослідження застосовували загальноприйняті методи системного і статистичного аналізу.

Результати й обговорення. Проаналізовано ринок МЛЗ станом на 2019 р. за видом ЛФ, складом ЛЗ, походженням АФІ, країною та фрірмою-виробником, а також за напрямком застосування, та встановлено, що в досліджуваному асортименті ЛФ переважають препарати іноземного виробництва (56 \%), найбільший відсоток із зареєстрованих МЛФ займають мазі (42,89\%), домінують монокомпонентні Л3 (64,63 \%) над комбінованими (35,37\%), переважають Мл3 синтетичного походження (61,99 \%). Порівняльний аналіз МЛЗ за період 2014 р. та 2019 р. показав, що асортимент зареєстрованих МЛ3 збільшився 3478 (2014р.) до 492 (2019р.) найменувань Л3; частка МЛ3 вітчизняного виробництва становить 44,11 \% (2019р.) і збільшилась на 9,39 \% порівняно 32014 р., тоді як частка МЛ3 іноземного виробництва знизилась від 65,28 \% (2014р.) до 55,89 \% (2019р.); зберігається тенденція домінування мазей, гелів та кремів із незначним зменшенням частки гелів у 2019 р. на 1,96 \% порівняно із 2014 р.; співвідношення між МЛЗ за галуззю застосування практично не змінилося - збільшилась частка Мл3, що використовуються у дерматовенерології (на 3,32 \%) та гінекології (на 1,34 \%). Висновки. За результатами порівняльного аналізу зареєстрованих ЛЗ у МЛФ у 2014 р. та у 2019 р. встановлено динаміку фрармацевтичного ринку досліджуваних препаратів. Актуальним залишається питання розширення асортименту вітчизняних МЛФ для застосування в різних галузях медицини.
\end{abstract}

Вступ. На сьогодні лікарські засоби (ЛЗ) у м'яких лікарських фрормах (МЛФ) мають широке практичне застосування у різних галузях медицини, проте найбільш часто застосовують при лікуванні дерматоло- гічних захворювань [1]. У відповідній монограсії, наведеній у ДФУ (II видання), зазначено, що м'які ЛЗ для нашкірного застосування призначені для місцевої дії або трансдермальної доставки активних фрар-

ISSN 2312-0967. Фармацевтичний часопис. 2020. № 4 
мацевтичних інгредієнтів, або для зм'якшувальної чи захисної їхньої дії [2]. Відповідно до фрармакопейної класифрікації, до м'яких ЛЗ для нашкірного застосування належать мазі, креми, гелі, пасти, припарки, пластирі лікувальні та пластирі нашкірні [2]. Як бачимо, лініменти відсутні у переліку МЛФ для нашкірного застосування, поданого у ДФУ. При виконанні маркетингових досліджень у 2014 р. асортимент МЛФ аналізували [3] відповідно до класифікації МЛФ, затвердженої наказом Міністерства охорони здоров'я (МО3) України від 26.06.2002 р. № 235, згідно із яким МЛФ поділялись на гелі, пасти, лініменти, креми, мазі, проте на сьогодні даний наказ втратив чинність. Окрім того, у І виданні ДФУ національним доповненням введено лініменти до переліку МЛФ для зовнішнього застосування. На сьогодні з погляду фрармакопейної класифікації лініменти розглядаються лише як вид екстемпоральної МЛФ, про що зазначено у монографрії «М'які лікарські засоби, виготовлені в аптеках (Unguenta ex tempore)» ДФУ (II видання) [4].

Відповідно до наказу МОЗ України від 20.07.2006 р. № 500 «Про затвердження переліків назв лікарських фрорм та упаковок до лікарських засобів» (чинний), ЛЗ різних груп можуть бути у вигляді МЛФ, наприклад, МЛФ у групі ЛЗ для орального застосування є гелі та пасти, у групі ЛЗ для ротової порожнини - оромукозні гель та паста, гель гінгівальний, нашкірні та трансдермальні препарати можуть випускати в таких м'яких формах, як креми, мазі, пасти, гелі, пластирі лікувальні, припарки. Креми, гелі та мазі є можливими МЛФ для очних, вушних, назальних, вагінальних та ректальних Л3 [5].

Аналіз наукових публікацій останніх років щодо дослідження ринку МЛФ вказує на те, що вивчення даного сегменту ринку ЛЗ проводили з погляду нозологічного застосування відповідно до АТСкласифрікації [1, 6-8].

Мета роботи: дослідження асортименту лз у вигляді МЛФ, що зареєстровані на фрармацевтичному ринку України станом на 2019 р., та проведення по-

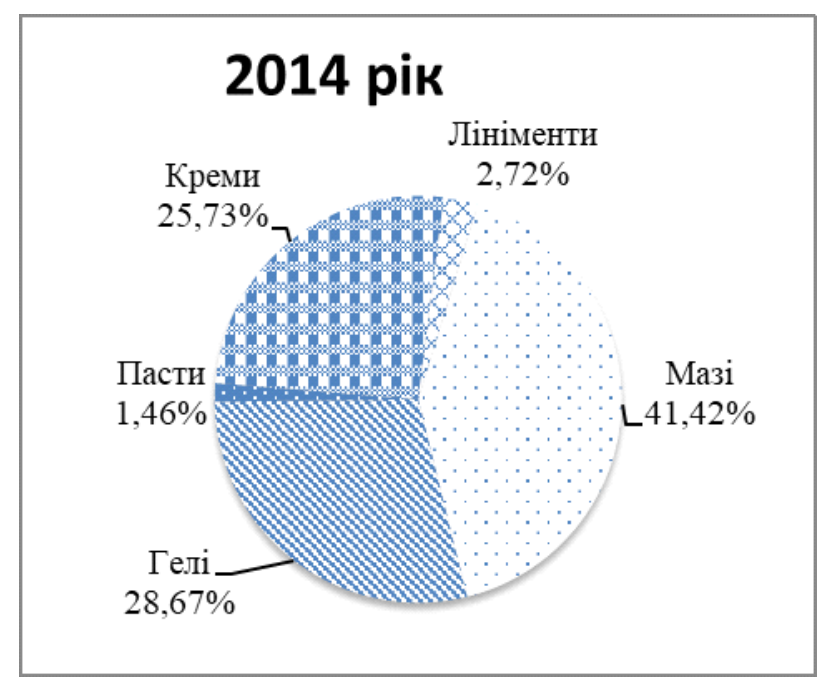

рівняльного аналізу зміни асортименту досліджуваних ЛФ впродовж 5 років (станом на 2014 р.).

Матеріали і методи. При дослідженні використовували методи системного і статистичного аналізу електронної та паперової інформації. Об'єктом дослідження була інформація про зареєстровані м'які лікарські засоби (МЛ3) на національному ринку станом на грудень 2019 р. відповідно до Державного реєстру ЛЗ України, розміщена на сайті «Нормативнодирективні документи МОЗ України», в довіднику лікарських препаратів Компендіум [9-11].

Результати й обговорення. Вивченню підлягали Мл3, які дозволені до застосування на території України, та відпускаються із аптек та їх структурних підрозділів. Для дослідження зміни асортименту лЗ м'якої форми випуску проведено порівняльний аналіз зареєстрованих МЛЗ на території України станом вересень 2014 р. та станом на грудень 2019 р.

За результатами аналізу Державного реєстру ЛЗ станом на грудень 2019 р. зареєстровано 492 найменування МЛ3, тоді як у вересні 2014 р. їхнє число склало 478 лЗ м'якої форми випуску. Із діапазоном спостережень у 5 років на фрармацевтичному ринку України кількість МЛЗ зросла на 14 препаратів. Прослідковується тенденція щодо збільшення кількості нових зареєстрованих МЛЗ при зменшенні кількості МЛЗ іноземного виробництва, зокрема, російського, та збільшенні препаратів вітчизняного виробництва.

Найбільший відсоток із зареєстрованих Лз м'якої форми випуску станом на 2019 р. займають мазі $42,89 \%$, гелі - 27,03 \%, креми - 25,20 \%, тоді як незначний відсоток займають лініменти - 2,85 \% та пасти - 2,03 \% (рис. 1).

Порівняльний асортиментний аналіз МЛФ показав, що лідируючі позиції як у 2014 р., так і в 2019 р. займають мазі, гелі та креми, а лініменти та пасти представлені значно менше (рис. 1).

У результаті аналізу МЛЗ за складом встановлено, що домінують монокомпонентні препарати, частка

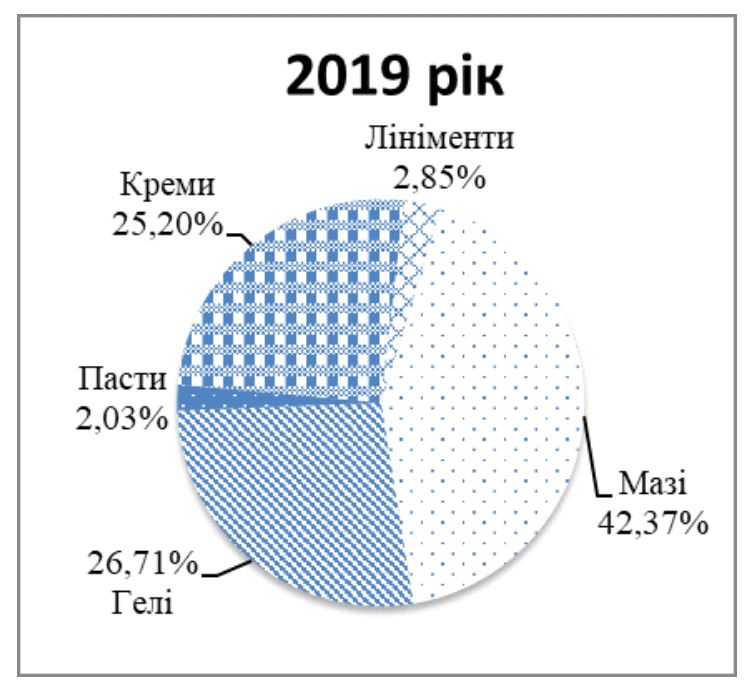

Рис. 1. Розподіл лікарських засобів м'якої фрорми випуску за видом лікарської фрорми.

ISSN 2312-0967. Pharmaceutical review. 2020. № 4 
Фармацевтичний менеджмент, маркетинг та логістика Pharmaceutical management, marketing and logistics

яких становить 64,63 \%, а комбінованим препаратам належить 35,37 \% ринку (рис. 2).

Досліджуючи розподіл МЛЗ за походженням АФ। визначено, що більшість ЛЗ $є$ синтетичного походження (61,99 \%). Частки комбінованих ЛЗ у МЛФ та МЛЗ із АФІ рослинного походження складають 18,91 \% та 12,60 \% відповідно, а Л3 із АФІ біологічного походження представлені значно менше (6,50 \%) (рис. 3).

Визначено, що на фрармацевтичному ринку України МЛЗ $з$ незначною перевагою домінують препарати іноземного виробництва, частка яких становить 55,89 \%. Загальна кількість вітчизняних МЛЗ становить 217 найменувань (44,11\%), що на 51 л3 більше, ніж у 2014 р. (166 найменувань), що свідчить про зростання обсягів вітчизняного виробництва. Щодо препаратів іноземного виробництва, то їх кількість на фрармацевтичному ринку України складає 275 Л3 (55,89 \%), тоді як у 2014 р. їх кількість становило 312 найменувань. Таким чином, результати порівняльного аналізу

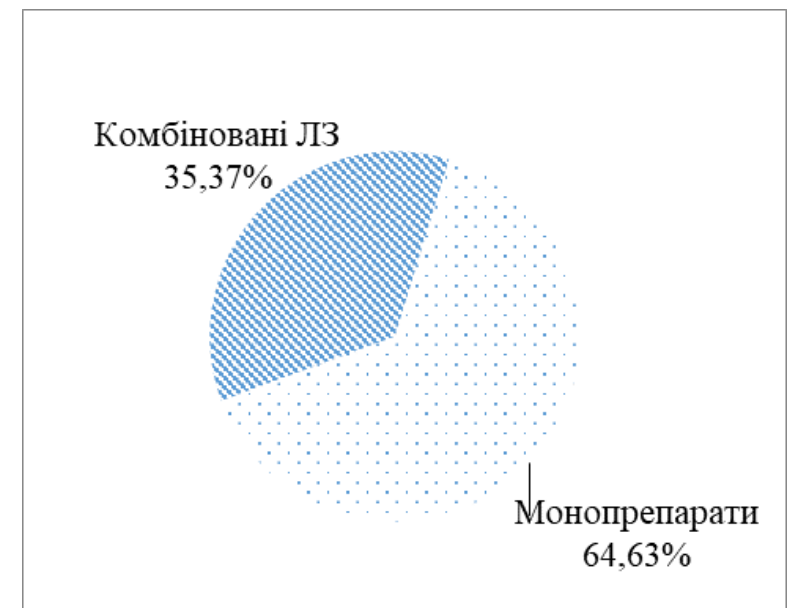

Рис. 2. Розподіл лікарських засобів м'якої форми випуску за складом препарату.



асортименту ЛЗ у МЛФ, які репрезентовані на фрармацевтичному ринку України в період 2014-2019рр., показують, що співвідношення між зареєстрованим МлЗ вітчизняного та іноземного виробництва дещо змінились: частка МЛЗ вітчизняного виробництва зросла від 34,72 (2014р.) до 44,11 \% (2019р.), тоді як частка МЛ3 іноземного виробництва знизилась від 65,28 (2014 р.) до 55,89 \% (2019 р.) (рис. 4).

Таким чином, ринок України все ще імпортозалежний, проте спостерігається зростання обсягів вітчизняного виробництва, особливо збільшилась кількість мазей, при цьому частка вітчизняних мазей переважає (рис. 5)

Аналіз асортименту ЛЗ у МЛФ за країнами-виробниками показав, що на українському ринку зареєстровані МЛ3 із 33 країн світу, що на 4 країни менше, ніж у 2014 році, серед них лідерами є Німеччина - 64 МЛ3 (23,75\%), Індія - 37 МЛ3 (13,45 \%), Польща - 25 МЛ3 (9,09 \%), Франція та Італія по 17 МЛ3 ( по

\section{Рослинного походження $12,60 \%$ \\ $61,99 \%$}

\section{Біологічного походження $6,50 \%$}

Комбіновані Л3 $18,91 \%$

Рис. 3. Розподіл лікарських засобів за походженням/ природою АФІ.

\section{PIK}

$\square$ Іноземного виробницта $\square$ Вітчизняного виробництва

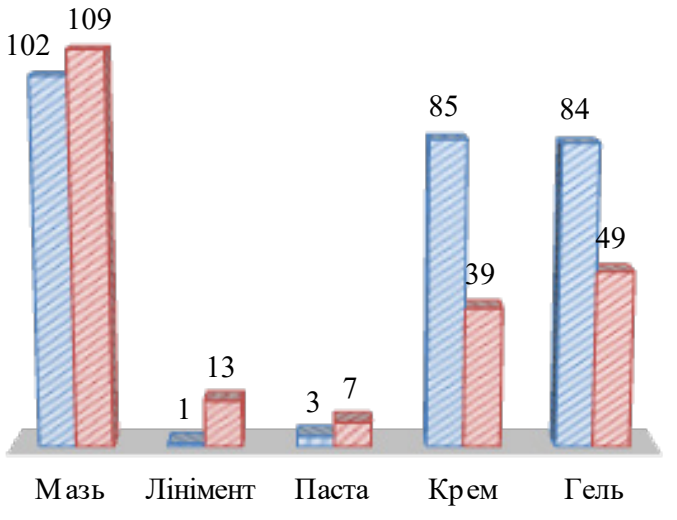

Рис. 4. Розподіл лікарських засобів м'якої фрорми випуску за вітчизняним та іноземним виробництвом.

ISSN 2312-0967. Фармацевтичний часопис. 2020. № 4 
Фармацевтичний менеджмент, маркетинг та логістика Pharmaceutical management, marketing and logistics



Рис. 5. Рейтингова шкала вітчизняних виробників за кількістю зареєстрованих лікарських засобів м'якої фрорми випуску на фрармацевтичному ринку України.

6,18\%), Хорватія - 13 мл3 (4,73 \%). Інші країни, імпорт яких не перевищує 10 препаратів, займають разом 36,62 \% українського ринку.

В Україні МЛЗ випускають близько 18 фрірмвиробників різної форми власності, із яких більша частина фрірм з'явилась на фрармацевтичному ринку за останні 15 років. Серед вітчизняних виробників лідируючі позиції займають ВАТ «Фітофрарм» (м. Артемівськ, Донецька обл.), ВАТ «Лубнифрарм» (м. Лубни, Полтавська обл.), ТОВ Фармацевтична компанія
«Здоров'я» (м. Харків) та ФФ «Віола» (м. Запоріжжя). М'які лікарські засоби широко застосовують у різних напрямках медицини, проте, незважаючи на популярність застосування МЛФ, їх використання в різних галузях медицини не $є$ рівномірним. Так, станом на 2019 р. 50,60 \% асортименту МЛЗ застосовують у дерматовенерології, значно менше Млз використовують у хірургії та ревматології (по 16,87 \%), частка МЛФ, які застосовують в інших галузях, порівняно незначна (рис. 6).
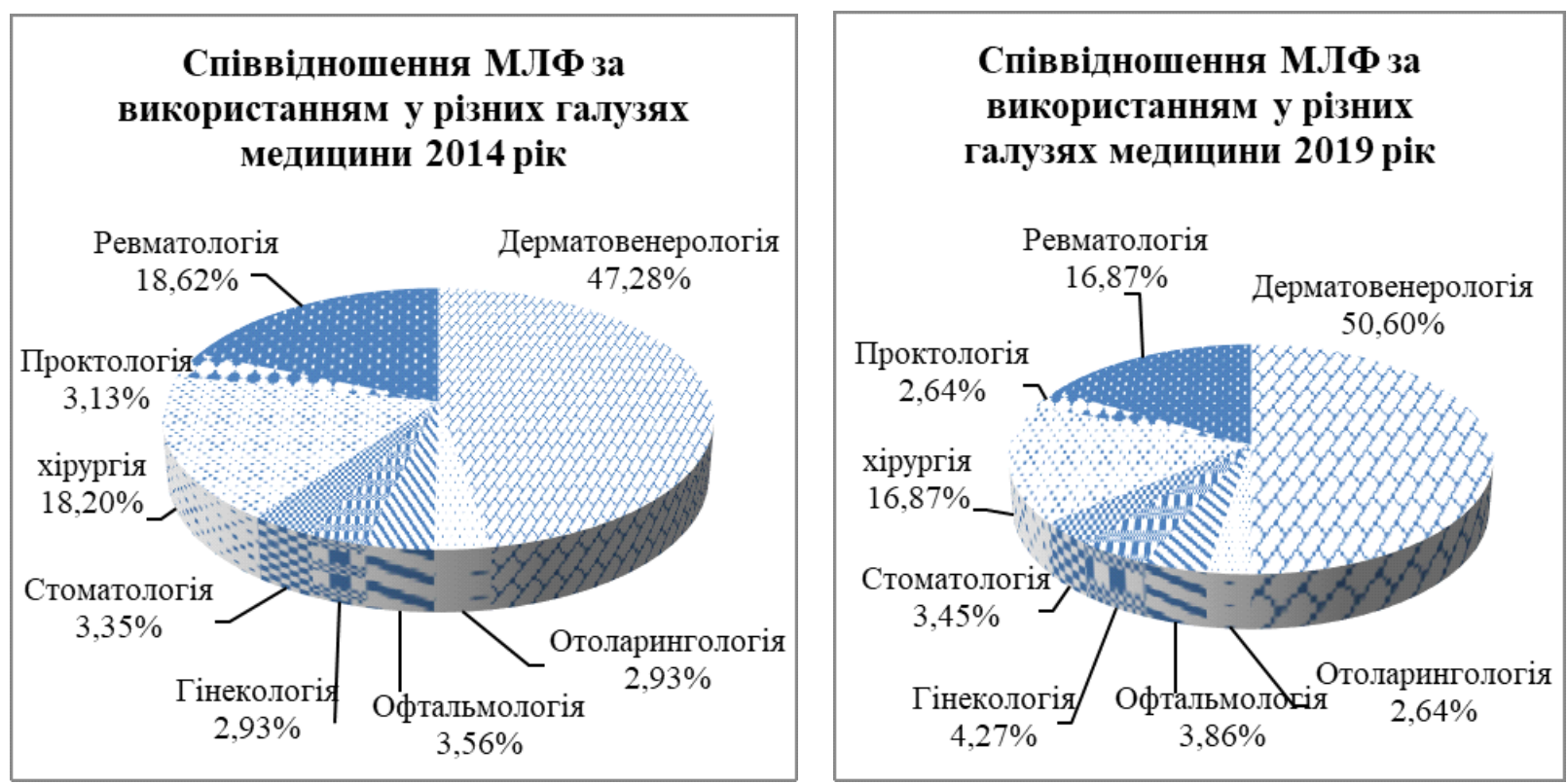

Рис. 6. Розподіл лікарських засобів м'якої фрорми випуску за напрямком застосування.

ISSN 2312-0967. Pharmaceutical review. 2020. № 4 
Фармацевтичний менеджмент, маркетинг та логістика Pharmaceutical management, marketing and logistics

Порівняня асортименту ЛЗ у МЛФ, які репрезентовані на орармацевтичному ринку України в період 20142019 рр., дає можливість зробити висновок, що співвідношення між галуззям застосування МЛФ практично не змінилися впродовж 5 років, дещо збільшилась частка МЛ3, що використовуються у дерматовенерології та гінекології; незначно зменшилась кількість МЛФ, які застосовуються в хірургії та ревматології.

На підставі отриманих результатів проведених комплексних досліджень можна зробити висновок про те, що актуальним на сьогодні $€$ збільшення асортименту готових МЛЗ із можливим застосуванням у різних галузях медицини, оскільки деякі препарати іноземного виробництва не мають вітчизняних аналогів.

Висновки. Вивчено асортимент МЛ3, зареєстрованих на території України та встановлено, що станом на грудень 2019 р. їхній арсенал налічує 492 препарати. Визначено, що український ринок на 55,89 \% складається із МЛ3 іноземного виробництва та на 44,11 \% вітчизняного виробництва. У досліджуваному асортименті переважають мазі (42,89\%), гелі та креми представлені менше $(27,03 \%, 25,20 \%)$, а частка лініментів та паст незначна (2,85 \%, 2,03 \%). Визначено, що переважають монокомпонентні (64,63\%) МЛФ із АФІ синтетичного походження (61,99 \%), а також пріоритетною галуззю застосування $€$ дерматовенерологія (50,60 \%). Результати порівняльного аналізу асортименту МЛЗ, які репрезентовані на фрармацевтичному ринку України впродовж 2014 р.-2019 рр., вказують на збільшення частки МЛФ вітчизняного виробництва (від 34,72 до 44,11 \%), зокрема, лЗ у вигляді мазей.

Конфлікт інтересів: відсутній.

Conflicts of interest: authors have no conflict of interest to declare

\title{
COMPARATIVE ANALYSIS OF THE RANGE OF SEMISOLID DOSAGE FORMS ON THE PHARMACEUTICAL MARKET OF UKRAINE
}

\author{
T. A. Hroshovyi, I. V. Blazhko, A. Yu. Shyrko, B. V. Pavliuk, M. B. Chubka \\ I. Horbachevsky Ternopil National Medical University \\ bohdana.vons@gmail.com
}

The aim of the work. To investigate the range of drugs in the semisolid dosage forms, registered in the pharmaceutical market of Ukraine as of 2019, and conduct a comparative analysis of changes in the range of studied drugs over 5 years (as of 2014).

Materials and Methods. The official sources of information on drugs registered in Ukraine in the semisolid dosage forms and preliminary results of marketing research were used. The study used generally accepted methods of systematic and statistical analysis.

Results and Discussion. The market of semisolid medicines was analyzed as of 2019 by type of dosage form, composition, the origin of active pharmaceutical ingredient, country, and manufacturer, as well as by area of application. In addition, found that foreign drugs (55.89\%) dominate the studied range of drugs, the largest percentage of registered semisolid dosage forms are ointments (42.89\%), dominated by monocomponent drugs (64.63 \%) over combined (35.37\%), and dominated by soft drugs of synthetic origin (61.99\%). A comparative analysis of soft medicines for the period of 2014 and 2019 showed that the range of registered soft medicines increased from 478 (2014) to 492 (2019) names of medicine. The share of soft medicines of domestic production is $44.11 \%$ (2019) and increased by $9.39 \%$ compared to 2014 , while the share of soft medicines of foreign production decreased from $65.28 \%$ (2014) to $55.89 \%$ (2019). The trend of the dominance of ointments, gels, and creams with a slight decrease in the share of gels in 2019 by $1.96 \%$ compared to 2014; the ratio between soft drugs by areas of application has not changed - increased the share of soft drugs used in dermatovenereology (3.32\%) and gynecology (1.34 \%).

Conclusions. According to the results of the comparative analysis of registered drugs in soft dosage forms in 2014 and in 2019 , the dynamics of the pharmaceutical market of the studied drugs was established. The issue of expanding the range of domestic soft dosage forms for use in various fields of medicine remains relevant.

Key words: semisolid dosage forms; pharmaceutical market; range.

ISSN 2312-0967. Фармацевтичний часопис. 2020. № 4 
Фармацевтичний менеджмент, маркетинг та логістика

Pharmaceutical management, marketing and logistics

\title{
СРАВНИТЕЛЬНЫЙ АНАЛИЗ АССОРТИМЕНТА МЯГКИХ ЛЕКАРСТВЕННЫХ СРЕДСТВ НА ФАРМАЦЕВТИЧЕСКОМ РЫНКЕ УКРАИНЫ
}

\author{
Т. А. Грошовый, И. В. Блажко, А. Ю. Ширко, Б. В. Павлюк, М. Б. Чубка \\ Тернопольский национальный медицинский университет имени И. Я. Горбачевского мОз Украины \\ bohdana.vons@gmail.com
}

Цель работы. Исследовать ассортимент лС в виде МЛФ, зарегистрированных на фрармацевтическом рынке Украины в 2019 г., и провести сравнительный анализ изменения ассортимента исследуемых ЛФ в течение 5 лет (на 2014 г.).

Материалы и методы. Использовали официальные источники информации о зарегистрированных в Украине ЛС в МЛФ и предварительные результаты маркетинговых исследований. При проведении исследования применялись общепринятые методы системного и статистического анализа.

Результаты и обсуждение. Проанализирован рынок МЛС 2019 г. по виду ЛФ, составу ЛС, происхождению АФИ, страной и фрирмой-производителем, а также по направлению применения, и установлено, что в исследуемом ассортименте ЛФ преобладают препараты иностранного производства (55,89 \%), наибольший процент среди зарегистрированных МЛФ занимают мази (42,89 \%), доминируют монокомпонентные ЛС (64,63 \%) над комбинированными (35,37 \%), в преимуществе МЛС синтетического происхождения (61,99 \%).

Сравнительный анализ МЛС за период 2014-2019 гг. показал, что ассортимент зарегистрированных МЛС увеличился с 478 (2014 г.) до 492 (2019 г.) наименований ЛС; доля МЛС отечественного составляет 44,11 \% (2019 г.) и увеличилась на 9,39 \% по сравнению с 2014 г., тогда как доля МЛС иностранного производства снизилась от 65,28 \% (2014 г.) до 55,89 \% (2019 г.); сохраняется тенденция доминирования мазей, гелей и кремов с незначительным уменьшением доли гелей в 2019 году на 1,96 \% по сравнению с 2014 г.; соотношение между МлС за направлениями применения практически не изменилось - увеличилась доля МЛС, используемых в дерматовенерологии (на 3,32 \%) и гинекологии (1,34\%).

Выводы. По результатам сравнительного анализа зарегистрированных ЛС в МЛФ в 2014 и в 2019 г. установлено динамику фрармацевтического рынка исследуемых препаратов. Актуальным остается вопрос расширения ассортимента отечественных МЛФ для применения в различных областях медицины.

Ключевые слова: мягкие лекарственные средства; фрармацевтический рынок; ассортимент.

\section{Список бібліографічних посилань}

1. Власенко І. Л., Давтян Л. Л. Порівняльний аналіз ринку дерматологічних лікарських засобів в Україні за 2013 та 2018 рр. Зб. наук. прац. співробіт. НМАПО імені П. Л. Шупика. 2018. № 29. С. 194-204.

2. Державна Фармакопея України: в 3 т. / Державне підприємство «Український науковий фармакопейний центр якості лікарських засобів». - 2-е вид. - Харків : Державне підприємство «Український науковий фрармакопейний центр якості лікарських засобів», 2015. Т. 1. 1128 с.

3. Державна Фармакопея України: в 3 т. / Державне підприємство «Український науковий фармакопейний центр якості лікарських засобів». - 2-е вид. - Харків : Державне підприємство «Український науковий фрармакопейний центр якості лікарських засобів», 2015. Т. 3. 732 с

4. Vons B. V., Chubka M. B., Groshovyi T. A. Market analysis of semisolid dosage forms registered in Ukraine and research of excipients included to their formulas. Фармацевтичний часопис. 2015. № 1. Р. 55-61.

5. Про затвердження Класифрікатора лікарських форм : наказ МОЗ України від 07.07.2006 р. № 500. URL: https://www.apteka.ua/article/3482

6. Глущенко О. М., Полова Ж. М. Дослідження ринку м'яких лікарських засобів, що сприяють загоєнню ран. Фармацевтичний часопис. 2019. № 4. С. 51-56.

7. Порівняльний аналіз асортименту лікарськихзасобів для місцевого лікування опіків на національному та закордонних ринках / Вонс Б. В., Чубка М. Б., Грошовий Т. А., Стечишин І. П. Фармацевтичний журнал. 2019. № 4. С. 4-11.

8. Немченко А. С., Кухтенко О. С., Гладух Є. В. Маркетингові дослідження ринку лікарських засобів для лікування варикозного розширення вен та запальних захворювань суглобів. Соціальна фрармація в охороні здоров'я. 2017. Т. 3, № 3. С. 66-73.

9. Нормативно-директивні документи МОЗ України. URL: http://mozdocs.kiev.ua

10. Державний реєстр лікарських засобів України. URL: http://www.drlz.kiev.ua/

11. Довідник «Компендіум». URL: http://compendium. com.ua

ISSN 2312-0967. Pharmaceutical review. 2020. № 4 


\section{References}

1. Vlasenko IO, Davtyan LL. [Comparative analysis of the market of dermatological drugs in Ukraine for 2013 and 2018]. Zbirnyk naukovykh prats spivrobitnykiv NMAPO imeni P.L. Shupyka. 2018;29: 194-204. Ukrainian.

2. The State Pharmacopoeia of Ukraine: in 3 vol. Kharkiv: Ukrainian Scientific Pharmacopoeia Center of Quality of Medicinal Products. Ed.2. Vol. 1. [Державна Фармакопея України: в 3 т. / Державне підприємство «Український науковий фрармакопейний центр якості лікарських засобів». - 2-е вид.] Kharkiv: Ukrainian Scientific Pharmacopoeia Center of Quality of Medicinal Products; 2015. Ukrainian.

3. The State Pharmacopoeia of Ukraine: in 3 vol. Kharkiv: Ukrainian Scientific Pharmacopoeia Center of Quality of Medicinal Products. Ed.2. Vol. 3. [Державна Фармакопея України: в 3 т. / Державне підприємство «Український науковий фрармакопейний центр якості лікарських засобів». - 2-е вид.] Kharkiv: Ukrainian Scientific Pharmacopoeia Center of Quality of Medicinal Products; 2015. Ukrainian.

4. Vons BV, Chubka MB, Groshovyi TA. Market analysis of semisolid dosage forms registered in Ukraine and research of excipients included to their formulas. Farm chasop. 2015;1: 55-61. DOI: https://doi. org/10.11603/2312-0967.2015.1.3766.
5. On approval of the Classifier of dosage forms: the Order of the Ministry of Health of Ukraine of July 07, 2006 No. 500. Available from: https://www.apteka.ua/ article/3482

6. Glushchenko OM, Polova ZhM. [Market analysis of wound healing semisolid drugs]. Farmatsevt chasop. 2019;4: 51-6. DOI: https://doi.org/10.11603/23120967.2019.4.10684. Ukrainian.

7. Vons BV, Chubka MB, Hroshovyi TA, Stechyshyn IP. [Comparative analysis of the range of drugs for the local treatment of burns in national and foreign markets]. Farm zhurn. 2019;4: 4-11. DOI: https://doi. org/10.32352/0367-3057.4.19.01. Ukrainian.

8. Nemchenko AS, Kukhtenko OS, Gladukh leV. [Marketing research of the pharmaceutical market of drugs for treating varicose veins and inflammatory diseases of joints]. Sotsialna farmatsiia $v$ okhoroni zdorovia. 2017;3(3): 66-73. DOI: https://doi.org/10.24959/sphhcj.17.87. Ukrainian.

9. Regulatory documents of the Ministry of Health of Ukraine. Available from: http://mozdocs.kiev.ua

10. State Register of Medicines of Ukraine [Electronic resource]. Available from: http://www.drlz.kiev.ua

11. Compendium Directory [Internet]. Available from: http:// compendium.com.ua.

\section{Відомості про авторів}

Грошовий Т. А. - д. фрармац. наук, профресор, завідувач кафредри управління та економіки фрармації 3 технологією ліків, Тернопільський національний медичний університет імені І. Я. Горбачевського МОЗ України, Тернопіль, Україна. E-mail: grochovuy@ukr.net, ORCID 0000-0002-6427-2158

Блажко І. В. - магістрант кафедри управління та економіки фрармації з технологією ліків, Тернопільський національний медичний університет імені I. Я. Горбачевського МОЗ України, Тернопіль, Україна. E-mail: blajko_ivva@tdmu.edu.ua Ширко А. Ю. - магістрант кафедри управління та економіки фрармації з технологією ліків, Тернопільський національний медичний університет імені І. Я. Горбачевського МОЗ України, Тернопіль, Україна. E-mail: hyrko_anyur@tdmu.edu.ua

Павлюк Б. В. - канд. фрармац. наук, асистент кафедри управління та економіки фрармації з технологією ліків, Тернопільський національний медичний університет імені І. Я. Горбачевського МОЗ України, Тернопіль, Україна. E-mail: bohdana.vons@gmail.com, ORCID 0000-0003-1276-0114

Чубка М. Б. - канд. фрармац. наук, доцент кафедри фрармації ФпО, Тернопільський національний медичний університет імені І. Я. Горбачевського МОЗ України, Тернопіль, Україна. E-mail: chubkacom@gmail.com, ORCID 0000-0002-5666-5496

\section{Information about the authors}

Hroshovyi T. A. - DSc (Pharmacy), Professor, Head of the Department of Pharmacy Management, Economics and Technology, I. Horbachevsky Ternopil National Medical University, Ternopil, Ukraine. E-mail: grochovuy@ukr.net, ORCID 00000002-6427-2158

Blazhko I. V. - graduate student of the Department of Pharmacy Management, Economics and Technology, I. Horbachevsky Ternopil National Medical University, Ternopil, Ukraine. E-mail: blajko_ivva@tdmu.edu.ua

Shyrko A. Yu. - graduate student of the Department of Pharmacy Management, Economics and Technology, I. Horbachevsky Ternopil National Medical University, Ternopil, Ukraine. E-mail: hyrko_anyur@tdmu.edu.ua

Pavliuk B. V. - PhD (Pharmacy), Department of Pharmacy Management, Economics and Technology, I. Horbachevsky Ternopil National Medical University, Ternopil, Ukraine. E-mail: bohdana.vons@gmail.com, ORCID 0000-0003-1276-0114 Chubka M. B. - PhD (Pharmacy), Associate Professor, Department of Pharmacy, Faculty of Postgraduate Education, I. Horbachevsky Ternopil National Medical University, Ternopil, Ukraine. E-mail: chubkacom@gmail.com, ORCID 00000002-5666-5496 